\title{
ČLANCI
}

UDK: 343.85:343.9.022

doi:10.5937/crimen1903215L

ORIGINALNI NAUČNI RAD

Prihvaćeno: 08.11.2019.

\author{
Klaus von Lampe 1 \\ Berlin School of Economics and Law, \\ Department of Police and Security Management
}

\section{TACKLING ORGANIZED CRIME: FROM THEORY TO PRACTICE ${ }^{2}$}

\section{INTRODUCTION}

The notion of organized crime provides a central reference point for the criminal policy debate around the globe. For at least two decades, since the drafting of the 2000 UN Convention against Transnational Organized Crime, there is broad agreement at national and international levels on the seriousness of the problem, and there is an increasing willingness to cooperate across institutional and jurisdictional boundaries in efforts to curb organized crime. Yet, there remains a great deal of uncertainty about the nature of the threat; and when it comes to concrete steps, like the ranking and prioritizing of threats, the selection of targets, and the choice of appropriate tools, there appears to be ample room for talking at cross purposes. In fact, there appears to be a conceptual vacuum underneath the surface of a concept that is well established in political, professional and public terminologies but only vaguely ties together myriad, often mythically distorted imageries. These imageries are by several degrees removed from the nitty-gritty crime phenomena that in their relative simplicity are self-explanatory, like the selling of drugs, the stealing of cars or the collection of protection payments. There is little in the way of categorizing these phenomena and, through an overarching, systematic and comprehensive conceptual framework, to link them back to the lofty concept of organized crime.

In the following sections, an attempt is made to fill this conceptual vacuum somewhat, and to sketch what a greater level of conceptual clarity implies for strategies that purport to be aimed at organized crime. The main contention is that organized crime is an umbrella concept for a number of rather different facets of social reality, which are not necessarily as closely related as the use of the term organized crime suggests and which, respectively, call for rather different preventive

1 Professor, klaus.vonlampe@hwr-berlin.de

2 Paper originally prepared for presentation at the Workshop "Advisory role of CSDP Missions in disrupting Criminal Organisations in host countries" - Järvenpää, Finland, October 2019 (Crisis Management Centre Finland, CMC) 
and repressive responses. Without making the necessary differentiations, it is argued, strategies against organized crime may well prove futile, misguided or even counter-productive.

The argument presented here incorporates three steps. In the first step, the history and meaning of the concept of organized crime as such is revisited. The second step entails systematically examining the phenomena that the concept of organized crime variously pertains to. In a third step, specific preventive and repressive approaches are deduced from the systematic analysis with a view to suitable points and methods of attack.

This discussion can only provide a rough outline of appropriate counterstrategies. The main emphasis is placed on categorical differences between pertinent phenomena and, correspondingly, categorical differences between appropriate countermeasures. No effort is made, however, to lay out a comprehensive and exhaustive masterplan for combating organized crime.

\section{A HISTORICAL AND SYSTEMATIC REVIEW OF THE CONCEPT OF ORGANIZED CRIME}

In order to devise appropriate strategies against organized crime it is important to understand, first of all, that organized crime is not a coherent and clear-cut phenomenon. It is not self-evident whether at all, or in reference to what one should speak of organized crime. In this respect it is quite revealing to review the conceptual history of organized crime.

The concept of organized crime began to take shape from the random combination of the two words "organized" and "crime" in the 1800s and early 1900s. In this process, quite different meanings were attached to this term; and the term was attached as a label to quite different phenomena. Organized crime referred to, for example, the polygamy of Mormons in Utah (Cragin, 1870: 22), to wars and atrocities committed in times of war and civil war (Spencer, 1881:23), to peasant uprisings in Ireland (Lewis, 1836: iii), to bands of highway robbers on India's countryside (Arnold, 1862: 264), to militant labor unions along America's West Coast (New York Times, 1907), and to the underworld of some thousands of professional criminals in Chicago (Sims, 1920). It was not until the 1950s and 1960s that the concept of organized crime gained sharper contours and some popularity, at least in the United States. What happened as a result of a series of highly publicized hearings before the U.S. Congress into illegal gambling and criminal infiltration of labor unions, that the term organized crime became synonymous with a very specific phenomenon: the Italian-American Mafia. In 1967, a commission convened by President Johnson famously stated that organized crime consists of 24 Mafia 'families' spread out across the United States (Task Force on Organized Crime, 1967: 7). Helped by the hugely successful novel "The Godfather" that was published in 1969 (Puzo, 1969) and subsequently turned into a series of equally successful movies released in 1972, 1974 and 1990, the notion of organized crime equaling a clannish, ethnically homogeneous criminal organization with influence over business and politics gained popularity around the world. In particular, there were law enforcement officials in a 
number of countries who began to wonder whether organized crime was something they should be concerned about. The problem was that with the narrow meaning of 'organized crime equals Mafia', the notion of organized crime remained largely hypothetical in places that did not resemble the crime landscapes of New York or Chicago. That was true even for many parts of the U.S., and certainly for many of the countries that sought to emulate the American way of life (Mack, Kerner, 1975; National Advisory Committee, 1976).

Eventually the notion prevailed that the term organized crime had to be reinterpreted. It had to be broadened to apply to a much wider spectrum of crime phenomena than those resembling the Italo-American Mafia in order to become widely applicable (see, e.g., the 2000 UN Convention against Transnational Organized Crime). What was not done in the process was to abandon the term organized crime because, apparently, law enforcement officials, policy makers, and journalists were hesitant to give up what Mike Levi (1998: 336) has called the "emotional kick" the term organized crime provides. In the end, some 200 years of conceptual history have not led up to a clear and unambiguous understanding of what organized crime is. Likewise, it is not possible to trace back the conceptual history to a pure, original understanding of organized crime to which one could return for conceptual clarity, unless one is willing to go back to the controversial and factually flawed Mafia imagery of the 1960s (for a critique see, e.g., Woodiwiss, 2001).

The extent of the conceptual confusion surrounding the notion of organized crime is evidenced by the more than 200 different definitions of organized crime that have been put forward in the past 70 years (von Lampe, 2019). None of these definitions is universally accepted; neither is it possible to reduce them to a minimal consensus. Instead, there are fundamental differences across various dimensions (von Lampe, 2016). A number of definitions equate organized crime in essence with criminal activity (Neumann, Elsenbroich, 2017: 1). A number of other definitions equate organized crime with the organization of criminals (e.g., Dobovšek, 1998: 680). Several definitions combine the two notions by saying that either organized crime is about certain types of crimes committed by certain types of criminal groups (e.g., Ignjatović, 1998: 25), or about certain types of criminal groups engaged in certain types of crimes (e.g., Valenčič, Mozetič, 2006: 130). Finally, there is the notion of organized crime representing a system or a systemic condition that goes beyond specific crimes or criminal groups (Block, 1983: vii; Homer, 1974: 4). This latter notion centers on the exercise of power. Clark (2005: 105), for example, speaks of organized crime in terms of "illegitimate loci of power."

There are also disagreements on lower levels of abstraction, for example, concerning the question what qualifies as a criminal organization. How many people do you need in order to have organized crime? Some definitions require at least two persons, some at least three, and some more than three. Some definitions require a formalized or a hierarchical structure. Other points of contention are whether the use of violence or corruption are defining characteristics of organized crime.

At its core, it seems, the whole notion of organized crime is fueled by three distinct focal concerns centering on three paradoxes. The first concern is with crime as a business. The underlying paradox is that crime is not always committed in the 'here' and 'now'; that crime can involve planning, sophistication, continuity, and as 
a result can be more efficient, more profitable and more difficult to deal with than spontaneous and impulsive acts of everyday criminality. The second focal concern behind the notion of organized crime pertains to the fact that not all criminals are lone offenders. Some criminals associate and cooperate with other criminals despite the risk that these are potential police informants and witnesses in court. By teaming up with others, criminals pool resources and at the same time diffuse individual responsibility. The third focal concern has to do with criminals assuming positions of power. This is the problem of extra-legal or illegal governance (Campana, 2011; Varese, 2011, Schelling, 1971). Criminals gain control over social spheres: neighborhoods, illegal markets, segments of the legal economy, and they come to regulate these social spheres for their criminal interests using criminal means. The paradox here is that crime that by definition is about undermining social order is actually creating order in areas where the state is not willing or able to perform its regulatory function.

These three focal concerns link organized crime to three basic dimensions across which pertinent phenomena vary: the organization of crimes, the organization of criminals, and the organization of social spheres by criminals for criminal purposes. It is important to stress, that these three dimensions are not just different sides of the same coin. There is a widespread notion that organized crime is a one-dimensional phenomenon going from bad to worse, and that in the end, if unchecked, there is a natural development towards an endpoint of highly sophisticated crimes being committed by highly sophisticated criminal organizations that are in firm control of their territory. Upon closer inspection, however, it becomes obvious that the phenomena labeled "organized crime" appear in very different constellations along those three basic dimensions. There may be rather unsophisticated street crime occurring under the control of a well-established underworld government, for example purse snatching and pickpocketing in Mafia strongholds in Palermo (Gambetta, 1993). There may be highly sophisticated crimes committed by highly sophisticated criminal groups in the absence of any kind of illegal governance, as is arguably true for many forms of organized economic crime (Friedrichs, 2010). One can also observe, for example, the commission of highly sophisticated crimes in the absence of elaborate criminal organizations and relatively little in the way of illegal governance, which seems to be characteristic of illegal online markets (Lusthaus, 2013). In other words, there is not a logical progression across all three dimensions from less to more organized crime. Rather, different constellations in the organization of crimes, criminals and social spheres appear to be contingent on specific conditions and situations.

\section{TOWARDS A THEORETICALLY GUIDED APPROACH TO COMBATING ORGANIZED CRIME}

The analytical approach outlined in the previous section has important implications for combating organized crime. Just like it is important to differentiate organized crime phenomena in order to avoid comparing apples and oranges it is important to consider what specific kinds of phenomena one seeks to tackle under the heading of 'tackling organized crime'. It has long been emphasized that there is no single solution, no universally valid approach to the problem of organized 
crime (Ploscowe, 1963). This follows from the diversity of crime schemes and crime markets, from differences across groups of offenders, and from the contingencies of different cultural, legal, social, economic and political contexts. Beyond these variations, however, categorically different approaches to organized crime can be deduced from the categorical differences between the basic dimensions of organized crime. This implies that devising responses to organized crime should start with considering where the problem lies: Is it about specific illegal activities, is it about particular criminal structures, or is it about illegal governance?

\section{Tackling organized illegal activity}

One of the questions discussed in the study of organized crime is what is more important: structures or activities. Do criminal organizations shape the crimes they commit, or does the nature of the crime determine how the perpetrators are organized? (Smith, 1994). A convincing argument can be made that at least under some circumstances, the latter is the case, and that offender structures are the "emergent properties" of criminal behavior (Cornish, Clarke, 2002: 52). Accordingly, it may well be a more efficient approach to target illegal activities irrespective of how the perpetrators engaging in these illegal activities are organized.

An example may clarify this point. In areas such as residential burglary or the theft of motor vehicles, law enforcement agencies may notice a reduction in crime after a particularly prolific offender group has been dismantled. This underscores the value of an offender-oriented approach. However, at the same time one should consider the crime reducing effects of preventive measures that target the mechanics of specific crimes, such as steering wheel locks, reinforced doors and windows, motion detectors and the like that make the commission of crime more difficult, more time consuming and less rewarding (Clarke, Eck, 2005). By limiting and eliminating crime opportunities, by depriving criminals of the resources they need to commit a particular type of crime, by disrupting the processes that are involved in the commission of a crime, it may become secondary or even obsolete to worry about offender structures. As soon as preventive measures set the hurdles for committing a particular crime sufficiently high, criminal groups may disintegrate by themselves or may not come into existence in the first place.

Measures that target illegal activities have to be crime specific with a view to, for example, logistics and modus operandi (Cornish, Clarke, 2002). However, the direction of countermeasures is also set at much higher levels of abstraction. For example, one important distinction is that between predatory crimes and marketbased crime. Preventing predatory crimes defined by offender-victim relations is about reducing vulnerabilities. Preventing market-based crimes centered on the provision of illegal goods and services is about tackling the supply and demand sides of illegal markets.

\section{Tackling criminal structures}

When criminal structures present themselves as appropriate targets, the first question to ask is: What kind of structures are at issue? In the study of organized crime, classifications of criminal structures tend to capture variations either with respect to form or with respect to function. 
With respect to form, a distinction is typically made between networks and organizations. Often, an implicit or explicit assumption exists that organizations, especially when they show some level of formalization and a hierarchy, are highervalue targets than less integrated and more fluid structures. This view, however, may overemphasize the importance of clear-cut, highly developed organizational structures. There are strong indications that the form of criminal structures is contingent upon endogenous and exogenous factors, and that it depends on the circumstances how efficient and dangerous certain forms of the organization of criminals are. For example, after the large and complex cocaine cartels from Cali and Medellin were dismantled in the 1990s, their place was taken by a large number of smaller groups while the cocaine trade as such was not profoundly disrupted (Decker, Townsend Chapman, 2008). In other words, depending on the situation, different forms of organization could essentially achieve the same outcome.

Arguably, classifying criminal structures by function - rather than by form - is much more relevant for devising preventive and repressive counterstrategies. In turn, failing to differentiate criminal structures by function is prone to lead to flawed assessments and decisions regarding the problem of organized crime. In terms of function, three types of criminal structures can be distinguished (von Lampe, 2016):

- entrepreneurial structures that are geared towards material gain;

- associational structures that serve social functions such as mutual support; and

- quasi-governmental structures that have as their raison dêtre the exercise of power.

These types can appear in pure form, serving only one function, or as hybrids serving more than a single function. In any case, it is important to keep the three functions analytically separate because they have wide ranging implications. To begin with, the inner workings of a structure are different depending, for example, on whether it is an illegal business geared towards interaction with the outside world to generate income, or a criminal association that is inwardly oriented to foster a sense of belonging and mutual support and trust among its members. Likewise, the motivation and inclination for individuals to form or join a particular structure varies with the purpose of that structure just as there are different factors that influence, respectively, the emergence of entrepreneurial, associational and quasi-governmental structures. Entrepreneurial structures emerge around crime opportunities. Associational structures are a response to the need of criminals to avoid social isolation in what tends to be a chaotic and hostile environment. Quasi-governmental structures, finally, fill a vacuum that is left by a state that is not willing or able to regulate certain spheres of society.

These categorical differences between functionally distinct criminal structures have direct implications for the choice of appropriate countermeasures. What may work well against entrepreneurial structures may not work in the same way and with the same level of success against associational or quasi-governmental structures.

Arguably, entrepreneurial structures most closely resemble targets of classical police work. In essence, it is about offenders that have to be linked to specific 
crimes, such as theft or fraud or the selling of drugs. The arrest and conviction of the perpetrators, the seizing of assets and possibly lengthy terms of incarceration all tend to have some immediate disruptive and incapacitating effect on the offender structure and may, ideally, lead to its disintegration.

Associational structures appear in a different light. What sets them apart especially from entrepreneurial structures is that they do not exist for the immediate purpose of committing crime, profit-oriented or otherwise. Associational structures as organizational entities rarely engage in criminal activity. They may commit crimes on occasion by violently disciplining members, or they may use violence in protecting their members against outside threats. Otherwise, however, associational structures tend to promote the criminal activities of their members only indirectly, for example by fostering trust and mutual support among the membership. Thus, unless there are specific laws in place that criminalize membership in an association (see Schloenhardt, 2012), there are relatively few starting points for criminal investigations against the members of criminal associations and against criminal associations as such. Yet, criminal associations deserve police attention for other reasons, namely to gain intelligence on potential co-offending networks that may emerge among members; or to undermine the cohesion of criminal associations in order to disrupt criminal networking and trust between criminals. Criminal associations may also be appropriate targets for administrative and legislative measures. For example, in the case of street gangs or criminal motorcycle gangs, bans on the wearing of uniform clothing and symbols can reduce the intimidation capital of individual members (Bjørgo, 2019).

Yet another situation presents itself in the case of quasi-governmental structures. Quasi-governmental structures are targeted in classic police work to the extent they engage in crime to establish, maintain and exercise power, typically through intimidation and the use of violence. However, once firmly entrenched, a quasi-governmental structure seldom has the need to openly engage in violence and intimidation (Gambetta, 1993; Reuter, 1994). Observable criminal behavior would then be limited to, for example, the collection of protection payments, although this tends to be done in low frequency on perhaps a weekly or monthly basis. Thus, similar to criminal associations, there may be few starting points for police investigations. In this situation, there is an understandable but analytically problematic tendency on the part of law enforcement agencies and legislatures to try to assign criminal responsibility to the leading figures of quasi-governmental structures - and of associational structures, for that matter - for the profit-making crimes committed by individuals under their protective roofs.

\section{Tackling illegal governance}

The preceding sections dealt with tackling illegal activities and criminal structures. Even though this also included a brief discussion of quasi-governmental structures, it makes sense to address the third basic dimension of organized crime, illegal governance, in a separate section because illegal governance is not necessarily linked to the exercise of power by a tangible structure that functions as an underworld government. Illegal governance can also involve individuals who, by virtue of their per- 
sonal reputation, resolve conflicts and arbitrate disputes. Similarly, there can be adhoc governance structures that are set up for dealing with a single issue, for example influential underworld figures sitting down to discuss how to respond to incursions from an outside criminal group. Finally, there can be illegal governance in the form of decentralized self-regulation of a criminal subculture. In this constellation, subcultural norms may empower individuals to take action directly against someone who has violated the underworld code of honor, for example in cooperating with the police, without having to refer the matter to some higher underworld authority.

The main remedy against illegal governance is reducing the power vacuum created by the state. In essence, this means enforcing and strengthening the rule of law. On one hand, it requires targeting those who commit crimes in the exercise of illegal power. On the other hand, it involves the strengthening of legal institutions of governance. For example, if criminals offer illicit debt collection services, a countermeasure could be increasing the effectiveness of the civil justice system by hiring more judges. In addition, undermining the resources and the reputation of those assuming positions of influence within the underworld is an approach that is valid even where distinct criminal groups are not a factor.

\section{CONCLUSION}

This essay sought to advance two interrelated arguments. One argument is a call for an analytical approach to organized crime. Organized crime is a historically grown umbrella concept driven by three distinct focal concerns regarding the organization of crimes, the organization of criminals, and the organization of social spheres by criminals. These focal concerns do not highlight different sides of the same coin but relate to separate phenomena that have to be examined and understood in their own right. The other argument is that corresponding to these categorical differences on the phenomenological level, the measures that purport to tackle organized crime have to be target-specific. While there are some overlaps, fundamentally different imperatives apply, respectively, to the targeting of illegal activities, criminal structures, and illegal governance. Similarly, on a lower level of abstraction, a differentiated view is necessary. For example, when the focus is on criminal structures, preventive and repressive measures have to consider the different functions that criminal structures may serve. While illegal businesses geared towards crime for profit present classical targets of police work, requiring detectives to link suspects to specific offenses, the situation is different for other types of criminal structures. Criminal fraternities that foster trust and cohesion among their members or underworld governments that exert control over their respective turf present fewer starting points for criminal investigations because they tend to be involved in criminal activities at a much lower frequency than illegal businesses.

The value and necessity of an analytical approach to tackling organized crime has only been sketched here in all brevity. A more refined elaboration of this perspective would need to take the specific nature of a crime problem and the specific setting into account. What may work in one country or in one jurisdiction may not work elsewhere. However, the contention is that the basic conceptual framework outlined here is universally valid and relevant wherever efforts are made to tackle organized crime. 


\section{REFERENCES}

Arnold, E. /1862/: The Marquis of Dalhousie's administration of British India. London, Saunders, Otley, and Co.

Bjørgo, T. /2019/: Preventing organised crime originating from outlaw motorcycle clubs. Trends in Organized Crime 22(1: 84-122.

Block, A.A. /1983/: East Side, West Side: Organizing crime in New York 1930-1950. New Brunswick, NJ, Transaction.

Campana, P. /2011/: Eavesdropping on the Mob: The functional diversification of Mafia activities across territories. European Journal of Criminology 8(3): 213-228.

Clark, M. /2005/: Organised crime: Redefined for social policy. International Journal of Police Science, Management 7(2): 96-109.

Clarke, R.V., Eck, J.E. /2005/: Crime Analysis for Problem Solvers: In 60 small steps. Washington DC, U.S. Department of Justice.

Cornish, D., Clarke, R.V. /2002/: Analyzing organized crimes. In: A.R. Piquero, S.G. Tibbetts (eds.), Rational Choice and Criminal Behavior: Recent Research and Future Challenges (pp. 41-62). New York, Routledge.

Cragin, A.H. /1870/: Execution of the Laws in Utah. Washington DC, F., J. Rives, G.A. Bailey.

Decker, S.H., Townsend Chapman, M. /2008/: Drug Smugglers on Drug Smuggling: Lessons from the inside. Philadelphia, PA, Temple University Press.

Dobovšek, B. /2008/: Economic organized crime networks in emerging democracies. International Journal of Social Economics 35(9): 679-690.

Friedrichs, D.O. /2010/: Trusted Criminals: White Collar Crime in Contemporary Society. $4^{\text {th }}$ ed. Belmont, CA, Wadsworth.

Gambetta, D. /1993/: The Sicilian Mafia: The Business of Private Protection. Cambridge, MA, Harvard University Press.

Homer, F.D. /1974/: Guns and Garlic: Myths and realities of organized crime. West Lafayette, IN, Purdue University Press.

Ignjatović, Đ. /1998/: Organizovani kriminalitet, drugi deo, Kriminološka analiza stanja u svetu. Belgrade, Policijska Akademija.

Levi, M. /1998/: Reflections on Organized Crime: Patterns and Control. Howard Journal of Criminal Justice 37(4): 335-438.

Lewis, G.C. /1836/: Local disturbances in Ireland. London, B. Fellowes.

Lusthaus, J. /2013/: How organized is organized cybercrime? Global Crime 14(1): 52-60.

Mack, J.A., Kerner, H.-J. /1975/: The Crime Industry. Westmead, Saxon House.

National Advisory Committee on Criminal Standards and Goals /1976/: Organized crime: Report of the Task Force on Organized Crime. Washington DC, Government Printing Office.

Neuman, M., Elsenbroich, C. /2017/: Introduction: the societal dimensions of organized crime. Trends in Organized Crime 20(1-2): 1-15.

New York Times /1907/: Undesirable Citizens. 25 April.

Ploscowe, M. /1963/: New Approaches to the Control of Organized Crime. The ANNALS of the American Academy of Political and Social Science, 347(1): 74-81.

Puzo, M. /1969/: The Godfather. New York, G.P. Putnam's Sons.

Reuter, P. /1994/: Research on American Organized Crime. In: R.J. Kelly, K.-L. Chin, R. Schatzberg (eds.), Handbook of Organized Crime in the United States (pp. 91-120). Westport, CT, Greenwood.

Schelling, T.C. /1971/: What is the Business of Organized Crime? The Journal of Public Law 20(1): 69-82.

Schloenhardt, A. /2012/: Fighting Organized Crime in the Asia Pacific Region: New weapons, lost wars. Asian Journal of International Law 2(1): 137-167. 
Sims, E.W. /1920/: Fighting crime in Chicago: The Crime Commission. Journal of the American Institute of Criminal Law and Criminology 11(1): 21-28.

Smith, D.C. /1994/: Illicit enterprise: An organized crime paradigm for the nineties. In: R.J. Kelly, K.-L. Chin, R. Schatzberg (eds.), Handbook of Organized Crime in the United States (pp. 121-150). Westport, CT, Greenwood.

Spencer, H. /1881/: The Industrial type of society. Popular Science 20(11): 1-29.

Task Force on Organized Crime /1967/: The Task Force Report: Organized Crime: Annotations and Consultants' Papers. Washington DC, Government Printing Office.

Valenčič, B., Mozetič, P. /2006/: Slovenia. In: T. Vander Beken (ed.), European organised crime scenarios for 2015 (pp. 95-135). Antwerp, Maklu.

Varese, F. /2010/: What is Organized Crime? In: F. Varese (ed.), Organized Crime: Critical Concepts in Criminology (Vol. I, pp. 1-33). London, Routledge.

von Lampe, K. /2016/: Organized Crime: Analyzing illegal activities, criminal structures, and extra-legal governance. Thousand Oaks, CA, Sage.

von Lampe, K. /2019/: Definitions of Organized Crime. www.organized-crime.de/organizedcrimedefinitions.htm

Woodiwiss, M. /2001/: Organized Crime and American Power: A History. Toronto, University of Toronto Press.

\section{Klus von Lampe}

Fakultet za ekonomiju i pravo, Berlin

\section{BORBA PROTIV ORGANIZOVANOG KRIMINALA: OD TEORIJE DO PRAKSE}

Autor nastoji da ispuni postojeći konceptualni vakuum u pojmovnom određenju raznovrsnih pojavnih oblika organizovanog kriminala u cilju jasnog i preciznog definisanja samog fenomena, što predstavlja preduslov za efikasnu borbu protiv njega.

Prvi deo rada posvećen je istorijskoj analizi koncepta organizovanog kriminala uz ukazivanje na raznoliku upotrebu ovog pojma (odnosio se na Mormone, indijske bande, čikaško podzemlje, italijansku mafiju itd). Nedostatak jedne univerzalno prihvaćene definicije ipak nije smetnja za određivanje tri glavne dimenzije ovog tipa kriminala: organizovanje zločina, organizovanje kriminalaca i angažovanje društvenih struktura od strane kriminalaca radi ostvarivanja kriminalnih ciljeva.

Drugi deo rada govori o tri aspekta borbe protiv organizovanog kriminala odn. davanju odgovora na pitanje "gde leži problem“ - u ilegalnim aktivnostima, kriminalnim strukturama ili ilegalnom upravljanju. Nadalje, optiranje između značaja strukture grupe ili zločina koji ta grupa vrši, autor rešava u korist same ilegalne aktivnosti kao takve i ističe bitnu ulogu preventivnih mera. Uz to, ukazuje se i na izdvajanje tri tipa organizacija: 1) preduzetničke strukture koje su usmerene ka sticanju dobiti 2) strukture koje imaju socijalnu funkciju 3) kvazi političke strukture koje teže osvajanju moći.

$\mathrm{Na}$ kraju, autor ističe i značaj jačanja vladavine zakona s posebnim osvrtom na strukture upravljanja (od strane moćnih pojedinaca ili ad hoc struktura usmerenih na rešavanje konkretnog problema).

Ključne reči: organizovani kriminal, ilegalne aktivnosti, strukture, upravljanje, mehanizmi reakcije. 